\title{
Demonstration position and strategic significance that Mao Zedong on protracted war in the ideological and moral education and culture
}

\author{
GuiLin Lu ${ }^{1, a}$, Zhou ZuoWan ${ }^{2, b}$ YuePing Cao ${ }^{3, c}$ \\ ${ }^{1}$ GuangXi University of science and Technology(GXUST), \\ No. 268 Donghuan Road, LiuZhou,P.R.China,545006 \\ ${ }^{2}$ SouthWest JiaoTong University, Chengdu,China, \\ ${ }^{3}$ Air force No.95275, LiuZhou,China,545006, \\ aemai:I mathsphysics@aliyun.com bemai:I zwzhou@swjtu.edu.cn, cemail: lifishspirit@126.com
}

Keywords: Seek truth from facts; on protracted war; humanitarian; cultivation

\begin{abstract}
According to the thought of Mao Zedong seek truth from facts, we discuss the theory of protracted war theory in the national survival and contribution to world peace, Particularly the application in the education and Research on the front, Mao Zedong's on protracted war theory, which runs through the leadership in the humanitarian and humanitarian and scientific practical significance and role, it summarizes the practical significance on protracted war in history and modern unity, demonstrates the necessity of long-term civic culture
\end{abstract}

\section{Introduction}

Mao Zedong Thought is the achievements of human civilization of Marx philosophy with China actually obtained brilliant The invasion of cancer cells within the blood flow around analysis ${ }^{[1]}$, "on protracted war" is an outstanding work, which is born during the Anti Japanese War period, it leads Chinese towards the victory of the Anti Japanese War, Mao Zedong is the masses of the leader who rely on the close contact with the history leading components of collective opinion, This work unite all can be united the power of justice, the Chinese nation is not only against foreign invaders, and the people to obtain the liberation, independence, autonomy, sovereignty, Communist ideology and individual can have a comprehensive development, its ideological value, in today's society it has realistic significance, In the world peace and development in the pattern, its essence is to constantly learn from Marx Lenin, science and technology to improve the nutrient, seek truth from facts in the world to explore the truth, self reflection and modestly study, sum up the experience in the long struggle to overcome the individualism, perfection, It embodies a nation and ethnic mutual dependence and tolerance, in order to achieve independence, total victory of democracy and freedom of education and training, it have epoch-making significance

\section{The reason which is in the ideological transformation work for the socialist countries national unity}

The construction of socialist countries Chinese has only sixty or seventy years, to a person, is very long, but for the country concerned, but is very brief, USA, Britain and France and other Western powers, has three hundred or four hundred years of state history of success, but the development is relatively slow, and Chinese is the emerging countries, the development of science and technology, strengthen patriotism consolidating national defense, education, peace and development, china has become an urgent task, there are more opportunities for learning and development,

"Knowing yourself, know yourself ${ }^{[2]}$, world are development today, energy, resources are different in various countries of the world, the development of science and technology in different degree, but each country required national energy is greater demand than ever before in history, the contradiction of supply and demand more and more prominent. Countries such as Japan, poor in natural resources, residence volcano, earthquake, tsunami occurs, small land area, population density is the first in the 
world, the history is not willing to through honest labor, solve the survival environment, Japan launched the war of aggression against its neighbors, to snatch the large amount of coal, oil and other national resources and mineral resources, heel to trample on the whole of Asia, even in the American has also been to the bombardment, until now, Japan is also pleaded guilty of death, erase history, one year repeatedly visited the Yasukuni Shrine, cause suffer Asian strong dissatisfaction and protest,

Although there are like Mr. Fujino honest scientists ${ }^{[3]}$ and students there, but they are often marginalized and are in danger of persecution. Some imperialist power, productivity, science and technology, education level is high, but it brought to the tendency of the color, is whether the dissatisfaction of the masses, directly or indirectly, for services to the military In this country, don't respect historical true colours, from the beginning of the preschool, they are told to Empire, chauvinistic ideas, racial qualities, to beautify the ancestors of external expansion, the reactionary history of aggression, crazy for the implementation of policies of aggression and war to create public opinion, the bourgeois world outlook is the great influence on each member country, Through their cultural are form, so that the majority of people's passive acceptance of "strong bullying the weak, Mei rich squeeze poor, rendering pornography, that bellicose belligerent education, formed for the service of the reactionary ruling class outlook on life, values and world view, a nation, do not understand the history, no future, so, the influence that the thought of different the national education for individuals is significant, Real and not fake socialist countries is not to each national unity of ideological remoulding ${ }^{[4]}$.

\section{Mao Zedong's position of the argument on protracted war ideological significance and strategic}

Scientific technology is always fighting force, and education is to impart knowledge as a valuable method for the accumulation of human, not the reactionary ruling class exclusive rights. Put this in the people in the Anti Japanese War, Mao Zedong thought is in Yanan practice, people can grow up to by the young, according to the physiological development step by step to receive appropriate education, it will be ready to battle the enemy, for the whole country and all the people, but also can develop the national physical bond., noble sentiment, the national interests in the first place, in order to have a clear direction and wide road in the transformation of world in action.

Ideological education is to follow the laws of nature to survive, the survival and development of a nation must be inclusive and ethnic mutual help and, in the long struggle to overcome the independence of egoism, democracy and freedom, all-round victory. Country, nation's survival and development,it is to transform the world's cognition of the world and to create a better life for human beings, is to form the correct world outlook process, Mao Zedong thought has the transformation of people's view of the world, and especially in the education on the successful experience, is to insist on the service of science and technology to the masses of the people, the national wealth created by honest labor, is The weak overcame the strong.,and is the national unity of experience.

We had analyzed the France as a typical capitalist country,he is one of the permanent members of the United Nations, and is the rule of law country, the French culture China Qian, the nuclear physicist, China communist revolutionary history, Deng Xiaoping, Zhou Enlai, Chen Yi, Zhu De and other students, the French scientific civilization really is spread to China, also broadcast there is scientific, democratic, academic freedom seeds,

So, the first one in France: he is that France ,and is a kind of China Communist Party on Chinese, especially,its history is unfavorable to the party period, although the French to the Communist Party and preconceptions, but can open one eye, one eye closed allow Communist activities in France, to keep the Chinese nation's outstanding children, Deng Xiaoping, Zhou Enlai, Chen Yi, Zhu De and other students, hope Chinese always thank the French culture, to be humble to learn French,he is a 
national survival, so we can understand why France experienced history burned Old Summer Palace disgraceful one page, but he is a big country, the overall with China cooperate, support Chinese,

The second kind of person is not who is in power,and is the most realistic, objective. The nature of science is honest, scientists have not only one but to serve the broad masses of the people, now the government about the people's livelihood, telling everyone living protection, everyone has a bright future, no matter as long as domestic production, life and orderly, then other countries want to rob Chinese wealth strategy will never succeed. The French see this point, he believe that the Communist Party is the service for the masses, the development of science for the broad masses of the people, France established diplomatic relations with China is willing to become friends, it willing to let China science especially ,in traditional Chinese medicine is a small corner, every year also sent students studying in China China scientific culture knowledge, promote scientific cooperation, development,

Third person is both historians and strategic military theory expert. Both scientists and political wisdom, character and prudent, to protect the national security, he believes that its national is good, but the Japanese invaders had still not guilty, this is French or America uncle Sam British Anglo Saxon feel hateful and terrible,

On protracted war idea is to mobilize the masses, unite the world progressive forces of all can be united, to build the new the Great Wall, the emergence of Bethune like a number of international communist fighter, is also the representative Chinese outstanding senior intellectuals, Chinese history never lack of patriotic intellectuals, Mao Zedong Thought Education of the world peace loving people, more is the humanitarian humanitarian and scientific practice, China Anti Japanese fascist struggle to get the world people's sympathy and support, and Mao Zedong Thought in the hearts of the people of the world take root, sprout, blossom, results......

Mao Zedong Thought with the international communist humanitarian brilliance, especially in the "equality" to the people, which is the symbol of human well-being, get support from all over the world and appreciation, written in the Chinese law, China humanitarian science both in theory and in practice, the army Zhou Enlai is a living textbook, crises to fall in the plane, one in the top Communist Party doesn't hesitate to parachute for an unrelated to teenagers, can imagine, the boy even foreign citizens, Zhou Enlai will not hesitate to put the students hope to others, rather than their own, there are greater than the Greek civilization, which is completely selfless, the Communist Party has embarrassed, dissident political opponents overwhelmed, people all over the world people think he will live in every heart, We will take every step, every teaching training through the patriotism, we have become a small part on the Great Wall, although small, but the unity is the foreign invaders.

3 Mao Zedong 's victory of the on protracted war theory in the foreign relations Of course, our unity is a principle, it is Mao Zedong on protracted war thought in the foreign relations of the victory, in scientific work, is to ensure that "science to grasp in the justice of the state and justice scientists hands", "scientific research before, everyone is equal", won Norbert Natural Science Awards for scientists with no title, as college students, in the published papers and project application, scientific activities, no privilege, published papers and research project end, learned scholars nationality and diploma. We are responsible for the development of science, more for the country for our strategies, the unity of the world scientific community, including Japan's scientific community.

Fair to say: Japan Science Group is also on the scientific development of the world made a contribution, Japan and China and difficult diplomatic, all Japanese, as long as compliance with China law, in China, and other foreigners Chinese friendly, all Japanese admit person is absolutely safe,

Japan's Meiji Restoration of prosperity is because there is a modest attitude, learning of science and culture and foreign advanced experience of running the country including China, 
Japan wants to own people better, Chinese, Americans in Japan, with Japanese in China American, China, is the person very safe, in order to Japan every citizen is responsible for the future, Japan will learn the two world war there have been failures in Germany, that have passed a few years ago, error, failure of aggression, you don't give yourself back their baggage, like Germany, is a wise choice, the people of the world are also willing to give the opportunity. Germany gave confidence. This is the national development must implement the introspection and self - examination, social can destroy human interests, in order to avoid extreme liberalism fallacy, in order to avoid personal development does not select any means, and to avoid according to of an imperialist war policy

Our productivity development level than the level of developed countries is still very low, in the development of science and technology productivity at the same time, we must also strengthen the moral education, intellectual education, aesthetic aspects of self-cultivation, as per the duty of a citizen, is a long-term task, because the masses is strengthen national defence, national survival and development must adhere to the socialist ideology, knowing the truth of the revolution,it is not possible in the spontaneous self motion of the masses and to form, and must have the leadership, we must have the leadership of the education system, in fact, Mao Zedong thought not only understand the interests of the masses and he is the most for the interests of the masses to struggle, but is also have the extremely rich knowledge of social science and natural science knowledge, and according to the construction and development of socialist and enrich, adhere to the leadership of the party, in fact Mao Zedong's theory of war lasting theory still has guiding significance for China's socialist economic construction

\section{Summary}

Mao Zedong Thought Theory and practice to carry out humanitarian humanitarian and scientific practice, points out that the national survival and development reflects how to deal with the relationship between national interests and personal interests, only by learning and using the survival and development of the law of nature, learning science and technology, but is also good at summing up the experience of historical development, the strategy for peace vision, developing national education, the core to the maximum extent overcome self-interest, the fate of each individual and the state, is linked to the fate of the entire world, embodies the justice of the state, the people of justice ,he should have the sense of social responsibility and conscience, this is the view of the world, Therefore, the construction of the Communist society also promotes the all-round development of the individual,

"we also own the hard" ${ }^{[5]}$, Mao Zedong thought learning is to the communism practice, and practice has unremittingly learning, human knowledge and conscience is in such persistence in circulation and will improve and expand, human knowledge is endless, Mao Zedong thought is rich in content, science and education as the main long-term development, is contribute to maintain world peace

\section{Acknowledgment}

(By 2014 China Association for science and technology funding, Research and action China Association of science and technology in the new modern country governance system and governance capacity status, and by The 2014 annual Guangxi Association for science and technology project research,etc.)

\section{References}

[1 Mao Zedong selection set, guoqing.china.com.cn,(2012)

[2] Sun Wu,The Art of War, The late spring and Autumn period of Qi 
[3] Lu Xun ,Mr. Fujino, Flowers of Mangyuan "bimonthly twenty-third issue of the first volume,(1926)

[4] Feng Ding, ordinary truth, Chinese Youth Press,2009.6, (1955),p95

[5] Xi Jinping, The whole Party must alert need to follow their own hardware,18 big since anti-corruption discourse,(2012) 